\title{
Doing 'dangerous' autoethnography on Islamophobic victimization
}

Irene Zempi, Nottingham Trent University, UK and Imran Awan, Birmingham City University, UK

\begin{abstract}
This article draws on our different experiences of employing autoethnography when researching Islamophobia, using two independent research projects. In particular, we reflect upon our experiences of Islamophobic victimization as a result of being 'visibly' Muslim in public spaces in the UK. We discuss our motivation for employing autoethnography and the role of our insider/outsider status in adopting the role of the Muslim 'other' in public spaces. Additionally, we consider the nature, extent and impact of Islamophobic victimization upon ourselves, and the coping mechanisms we employed to deal with it. The article concludes by reflecting upon the advantages, ethical challenges and limitations of using autoethnography when researching Islamophobic victimization.
\end{abstract}

\section{Keywords}

autoethnography, Islamophobia, insider/outsider, Muslims, victimization

\section{Introduction}

Autoethnography is a qualitative research method that uses the researcher's personal experiences as primary data in order to describe, analyse and interpret the sociocultural meaning of such experiences (Chang, 2016). Autoethnography employs self-observation and reflexive investigation, for the purposes of understanding the researcher's lived experiences and extending sociological understanding (Sparkes, 2000). As such, self-reflexivity and emotionality are at the core of autoethnography (Styhre and Tienari, 2014). However, despite recent accounts of the role of emotion in criminology and in research (see, for example, Liebling, 1999; Ferrell, 2006; Jewkes, 2011; Phillips and Earle, 2010), accounts of the self are usually absent in criminological research. In the words of Wakeman (2014: 705), 'most criminologists do not like to talk about themselves and their feelings very much'. This has often been attributed to the ways in which the discipline is structured as a social science - requiring researchers to minimize their selves, 'viewing self as a contaminant and attempting to transcend and deny it' (Wall, 2006: 147).

The positivism paradigm, which is typically seen as the scientific approach to research, promotes the objective measurement of social issues (Charmaz, 2006). According to Payne (2004), the terms and concepts used to demonstrate rigour in quantitative research (namely reliability, validity, representativeness, generalizability and objectivity) are problematic for qualitative research and specifically for (auto)ethnography. Founded on postmodern ideas, 
autoethnography rejects positivist notions of truth and validity. Rather, it focuses on the researcher's experiences, feelings and emotions, and uses self-reflexivity to connect the 'self' with the 'social' (Campbell, 2016).

Against this background, this article draws on our different experiences of employing autoethnography when researching Islamophobic victimization, using two independent research projects. In particular, we reflect upon our experiences of Islamophobic victimization as a result of being 'visibly' Muslim in public spaces in the UK. We discuss our motivation for employing autoethnography and the role of our insider/outsider status in adopting the role of the Muslim 'other' in public spaces. Additionally, we consider the nature, extent and impact of Islamophobic victimization upon ourselves, and the coping mechanisms we used to deal with it. The article concludes by reflecting upon the advantages and ethical and moral challenges, as well as the limitations, of using autoethnography when researching Islamophobic victimization.

\section{Understanding autoethnography}

In the 1970s, anthropologist Karl Heider first used the term 'autoethnography' to describe the way in which members of a culture could give accounts about their own experiences (Heider, 1975). David Hayano (1979) then used the term to refer to anthropological studies by individuals of their own culture. In this respect, autoethnography was narrowly defined as 'insider ethnography'. Although Heider and Hayano brought autoethnography into the research lexicon, the traditional notions of ethnographic research endured on the basis that there was a separation between the researcher and the researched (Campbell, 2016). Propelled by a 'crisis of representation', social researchers in the 1980s began to 'radically rethink' the way that they conducted research; autoethnography emerged as a method which allowed research to be done on one's self (Campbell, 2016: 96).

More recently it has been argued that 'the meanings and applications of autoethnography have evolved in a manner that makes precise definition difficult' (Ellingson and Ellis, 2008: 449). Indeed, the exact definition of the concept of autoethnography is elusive. Nevertheless, the consensus view is that autoethnography relies on using and analysing the researcher's own experiences. Typically, autoethnography ranges from studies in which the researcher's experiences are explored alongside those of the participants, through to stories in which the researcher's experiences become the actual focus of investigation (Ellis and Bochner, 2000). Denshire and Lee (2013) observe there are two main strands of autoethnography, 'evocative' and 'analytic' autoethnography. The evocative (also called 'emotive') approach foregrounds the researcher's personal stories. In this respect, autoethnographers tend to focus more on the self rather than the social world (Denzin, 2006). In contrast, analytic autoethnography connects to 'some broader set of social phenomena than those provided by the data 
themselves' (Anderson, 2006: 387). The purpose of analytic autoethnography is not simply to document personal experiences and provide an insider's perspective; rather, its purpose is to use empirical data in order to gain insight into some broader set of social phenomena than those provided by the data themselves (Wakeman, 2014). In other words, the goal is not just to capture emotional and evocative content but rather to develop a broad critical analysis of any given social phenomenon through it.

This binary classification is useful as an initial way of making visible the variation in how autoethnographic writers integrate the strands of self and culture in their writing (Denshire and Lee, 2013). Correspondingly, the two independent research projects subscribe to the analytic approach, using our personal experiences as empirical data in order to gain insight into the role of Muslims' visible religious identity in 'triggering' Islamophobia in public spaces. Before reflecting on our experiences of Islamophobic victimization as visible Muslims, it is first important to contextualize this discussion by offering an overview of the two research projects.

\section{Methods}

The findings in this article are based on two independent research projects that we are attempting to bring together in order to compare our experiences of researching Islamophobic victimization through autoethnography. Following terrorist attacks such as $9 / 11$ in the USA and 7/7 in the UK, there has been much discussion about the growth of Islamophobia in the West (see, for example, Allen, 2010; Esposito and Kalin, 2011; Poynting and Mason, 2007; Sayyid and Vakil, 2011). However, this discussion has not been accompanied by as much empirical analysis of Islamophobic victimization as one might expect (Moosavi, 2014). Yet in recent years, qualitative research into the experiences of Muslim women who wear the niqab (face veil) has been conducted in five European countries: Belgium, Denmark, France, the Netherlands, and the UK (Brems, 2014). Indeed, the data from qualitative interviews in these five countries show very strong similarities, namely, harassment and abuse of veiled Muslim women by strangers in public places. For example, veiled Muslim women in the Netherlands reported regularly being confronted with people who scolded, insulted or spat at them (Moors, 2009, 2014). Some also mentioned being physically threatened, with cars attempting to hit them, people throwing things at them or trying to pull off the niqab (Moors, 2009, 2014). Echoing these experiences, veiled Muslim women in the UK and France described a stream of violent insults in public places including being violently pushed, spat on, and having their niqabs pulled off (Boutelja, 2011). Along similar lines, the research literature demonstrates the vulnerability of 'visible' Muslim men as victims of Islamophobia in public places (Abbas, 2004; Hopkins, 2007; Mac an Ghaill and Haywood, 2014). This article attempts to fill in 
a gap in the current literature discussing Islamophobia: the gap of using autoethnography to research Islamophobia.

Irene's research project examined veiled Muslim women's experiences of Islamophobic victimization in public in the UK (Zempi, 2014). The study took the form of a qualitative study based on individual and focus group interviews with veiled Muslim women coupled with autoethnography whereby Irene wore the full veil for prolonged periods of time in public. The fieldwork took place in Leicester between 2011 and 2012. Specifically, the study was comprised of 60 individual and 20 focus group interviews with veiled Muslim women who had been victims of Islamophobia. Individual, in-depth interviews allow for 'rich' data to be collected with detailed descriptions (Hennink et al., 2011). This approach is especially valuable for researching sensitive issues that require confidentiality and a more intimate setting for data collection, and this is especially appropriate for 'hard to access' groups such as veiled Muslim women. Focus group interviews incorporate the strengths of qualitative research in terms of gathering 'rich' data whilst generating additional insights through group interactions (Curtis and Curtis, 2011). In the context of this particular piece of research, the focus group method afforded the possibility of open discussion amongst veiled Muslim women with similar or different experiences of Islamophobic victimization whilst, at the same time, highlighting collectively held beliefs and attitudes.

As mentioned above, the study also included autoethnography whereby Irene wore the full veil - including jilbab (long dress), hijab (headscarf) and niqab (face veil) - for prolonged periods of time in public. However, it is important to point out that employing autoethnography was not part of Irene's original research methodology. When Irene was initially developing her research project, her plan was to use individual and focus group interviews with veiled Muslim women. However, while she was doing the pilot interviews, some participants suggested that Irene should wear the veil in order to see for herself the level of abuse and hostility that veiled Muslim women suffered on a daily basis. By adopting their dress code, the aim was for Irene to become an 'insider' and thus feel part of their 'reality'. Some participants actually insisted that Irene wear the veil in order to accurately interpret their stories and represent their 'voices' regarding the nature, extent, and impact of Islamophobic victimization. In light of this, Irene decided to wear the veil as part of her daily routine in public places in Leicester. This aspect of the research followed an open-ended process. The main research question was: 'How does Irene's perceived identity as a veiled Muslim woman render her vulnerable to Islamophobic victimization in public?' Throughout the fieldwork, Irene kept a personal diary in order to write her reflections.

Imran has been researching the nature, extent and impact of Islamophobia for the last decade. Although he is a Muslim, Imran's religious identity is not visibly 
identifiable in terms of his appearance. For example, he does not have a beard and does not dress in traditional Islamic clothing. In 2015 Imran was interviewing some participants as part of a qualitative study on Islamophobia. All the participants in this study were 'visibly' identifiable Muslims. During the interviews, Imran's status as a non-visible Muslim was challenged by one of the male participants, Mohammed. Mohammed had a beard and wore the Islamic cap as well as traditional Islamic clothing, and thus he could be perceived as a 'visibly' practising Muslim because of his appearance. Mohammed said to Imran: 'Look Imran, you don't dress as a Muslim, you simply don't know how it feels like'. Although Imran has routinely suffered abuse online for researching Islamophobia, he has never experienced Islamophobic abuse in public, possibly because he is not identifiable as a Muslim. In light of this, Imran decided to employ autoethnography in order to research Islamophobia through adopting a 'visibly' identifiable Muslim identity in public spaces. In particular, Imran decided to grow a beard and wear the jubba (male Islamic dress) and Islamic cap as part of his daily routine in Birmingham, which is where he lives and works. The main research question was: 'How does Imran's perceived identity as a Muslim man render him vulnerable to Islamophobic victimization in public?' The fieldwork took place between August and September 2015. Imran recorded his experiences, feelings and emotions in a personal diary. The various situations that we encountered because of our perceived Muslim identity resulted in being subjected to verbal abuse, harassment and potential physical attacks.

\section{Irene's experiences 'in the field'}

Irene's experiences of harassment and intimidation as a result of her perceived Muslim identity in public included name-calling, swearing, threats of physical violence and derogatory forms of humour. Underlying all these forms of verbal abuse was a clear sense of anti-Muslim hatred and hostility, which was made apparent through the language used by the perpetrators. For example, typical examples of the name-calling Irene experienced included 'Muslim terrorist', 'suicide bomber' and 'You lot are terrorists', which indicated the perpetrators' perceptions of veiled Muslim women as a security or terrorist 'threat'. Indeed, research demonstrates that 'visible' Muslims and veiled Muslim women in particular are often targeted because their abusers hold the view that all Muslims are terrorists or terrorist sympathizers (Allen et al., 2013; Githens-Mazer and Lambert, 2010). From this perspective, the veiled female body offers a visual representation of 'radical Islam'. Additionally, Irene was subjected to swearing such as 'Muslim whore', 'f******* bitch', 'f******* freak', 'Muslim scum' and 'Your religion is filth'. The comments and/or gestures perpetrators made were often threatening, as indicated in the following diary extracts:

A group of white British men shouted at me 'We will burn your f******* Quran. You Muslims kill Christians, so all of us Christians 
will come kill all of you Muslims. We want to teach your kind a lesson.' I reckon they are EDL members because they are carrying EDL flags. I feel very intimidated and I am worried that they might be carrying a weapon.

A skinhead man made knife gestures at me whilst I was walking on the street. I feel like a walking target. I fear for my life.

I was minding my own business when a white male came close to me and started making explosion sounds at me. He asked me 'how many people have you lot killed in the name of Islam?'

As these experiences demonstrate, the wearing of the veil carries connotations of gender inequality, religious extremism, lack of integration, and threats to 'British/ Western ideals' (Chakraborti and Zempi, 2012). The niqab is often referred to as the 'icon of the intolerable difference' between 'us' and 'them' (Scott, 2007: 5). Furthermore, there were incidents where the nature of the verbal abuse suggested Islamophobic, racist and xenophobic sentiments, as demonstrated in the following diary extracts:

I was walking on the street today and a group of teenagers began mocking my niqab and swearing at me. They told me to ' $\mathrm{F}^{* * *}$ off back to Afghanistan' and one of them also shouted 'EDL, EDL, EDL!'

I was on the bus going home and an elderly man moved seats as I sat next to him. When I got off the bus he told me 'You're not welcome here, go back to where you came from'.

As the last quote indicates, Irene was targeted for being perceived as 'different' and 'other'. Grillo and Shah (2012) point out that the wearing of the veil marks an unwelcome religious, cultural and racial presence. In the eyes of their abusers, veiled Muslim women are seen as immigrants who 'don't belong' and thus 'they are not welcome' in the UK. This type of targeted hostility can be seen as a 'message' which is designed to tell the wider Muslim community that they are 'unwelcome' and 'don't belong', thereby extending the impact of this victimization beyond the actual, immediate victim to instil fear in the whole of the targeted community (Chakraborti and Garland, 2009). In particular, Perry and Alvi (2012) note that the perpetrator is sending a 'message' to four distinct audiences. First, to the peer group, that needs to be assured that the perpetrator is 'one of them', typically a straight, white, Christian male. Secondly, to the victim, who needs to be punished for his or her inappropriate performance of identity. Thirdly, to the victim's community, who need to learn that they too are vulnerable to the same fate, that they 'don't belong' or 'aren't to be tolerated', and finally, to the broader 
community, who are reminded of the appropriate alignment of 'us' and 'them'. Furthermore, Irene was targeted for being white and visibly Muslim through wearing the veil, as the following quote indicates:

I was targeted by two teenage boys as I was leaving the train station. One of them was very aggressive and intimidating, shouting 'Whites are not meant to be Muslim' and told his friend 'Pull that thing off her face'.

On one level, when a veiled Muslim woman is targeted the offender will not be certain of the ethnic identity of the victim; however, being white indicates that this person is likely to be a convert to Islam. From this perspective, white veiled Muslim women are routinely perceived as British converts and thus they are targeted for their decision to convert to Islam. In the eyes of their abusers, converts have supposedly betrayed the British/Western values and thus they are often called 'traitors'. This discussion highlights the notion of 'intersectionality' of identities. Intersectionality can be understood as a nexus of identities that work together to render certain individuals as 'ideal' targets to attack (Yuval-Davis, 2011). This indicates that the targeted victimization of veiled Muslim women can be attributed to Islamophobic attitudes as well as to racist and xenophobic sentiments by virtue of the fact that these elements are often inextricably intertwined. In this regard Islamophobia, racism and xenophobia become mutually reinforcing phenomena, and hostility against veiled Muslim women should also be considered in the context of a more general climate of hostility towards 'otherness' (Zempi and Chakraborti, 2014).

The extent and frequency of Islamophobic hostility that Irene experienced varied considerably. The most common locations to be targeted were in the 'white' areas in Leicester, whilst she rarely received any negative attention in the Muslimdominated areas in Leicester. This demonstrates the significance of geography in rendering veiled Muslim women vulnerable to Islamophobic victimization. Similarly, throughout interviews and focus group discussions with veiled Muslim women in Irene's (Zempi, 2014) study, participants highlighted that the level of abuse that they suffered depended upon whether they were in their local community or whether they left their 'comfort zone', sometimes taking the bus to go to less familiar areas that did not accommodate 'difference' and Muslim 'otherness' in particular.

While in most cases verbal abuse was momentary when walking on the street, or while waiting for the bus, in other cases Irene was subjected to sustained periods of 'low-level' hostility, particularly when stuck within a confined space, such as on public transport or in a shop. 'Low-level' and everyday acts of hate and hostility have a 'drip-drip' effect that magnifies feelings of vulnerability; nevertheless, the 
cumulative harms of the more 'ordinary' everyday forms of Islamophobic hostility often go unacknowledged. In particular, unnecessary or persistent staring, dirty looks, being ignored and refused service were common examples of 'low-level', everyday hostility throughout Irene's experiences as a veiled Muslim woman. Evidence shows that 'low-level' hate crime incidents form part of an ongoing process of hate crime victimization that is repeated over protracted periods of time, sometimes escalating into threatening and abusive behaviour and to physical violence (Walters et al., 2016). These often seemingly inconsequential incidents are not always captured by official statistics (police-recorded hate crime) or within victim surveys, which means that large data on hate crime do not necessarily capture the frequently routine nature of 'low-level' and everyday acts of hate and hostility (Walters et al., 2016). To this end, 'low-level' and everyday acts of hate and hostility remain 'invisible' in official statistics. The following accounts are taken from Irene's research diary to illustrate examples of 'low-level', everyday hostility in terms of being ignored and refused service.

I am in the fruit market in town and the stall owner refuses to serve me. I feel humiliated and ashamed.

I am waiting in the queue to pay for an item in a shop. In front of me there is a white man who is served immediately. The person at the till seems to ignore me. I can't help thinking 'is it because I'm wearing the veil?' I feel angry as I am a regular customer at this store but it seems that the moment I put on the veil, the quality of customer service changes from excellent to zero.

Furthermore, physical attacks were much less common than verbal forms of abuse, with the exception of a passing car that threw eggs at Irene, as indicated in the following diary extract:

I feel quite upset as a car drove past me and a white male threw eggs at me and then he shouted something about Muslims. I am so shocked that I did not manage to get the car's number plate.

Similarly, veiled Muslim women who took part in Irene's (Zempi, 2014) study described incidents where people on the street or from moving cars had thrown eggs, stones, alcohol, water bombs, bottles, take-away food and rubbish at them. Moreover, several participants described suffering physical abuse such as having the veil removed, pushing, shoving, being beaten up and even incidents where passing vehicles had attempted to run them over. Nevertheless, Irene felt somewhat 'lucky' because, unlike some of these participants who had suffered more serious incidents of physical abuse, she had experienced mostly 'low-level' manifestations of Islamophobia. However, knowledge of these incidents 
heightened her concerns that verbal abuse could escalate into violent assault. Indeed, Irene was afraid that she could suffer similar experiences. Irene felt that she was equally vulnerable to physical abuse because of the visibility of her perceived Muslim identity, and thus she was scared for her safety in public. Similarly, experiences of Islamophobic victimization increased feelings of insecurity, vulnerability and anxiety amongst the veiled Muslim women who took part in Irene's (Zempi, 2014) study. Bowling (2009) states that persistent victimization can undermine the security of actual and potential victims, and induce fear and anxiety. As a result, a common sensation cited by veiled Muslim women is that of panic attacks, worry, extreme anxiety and depression, which stems from the fear of having to endure future victimization.

Indeed, verbal attacks coupled with the possibility of suffering physical attacks affected Irene emotionally, including feeling afraid, shocked and/or upset on particular occasions. Such feelings were particularly pronounced immediately after an incident, but they seemed to develop into longer-term anxieties. Irene gradually developed sleep problems and lost her appetite. Moreover, there were days when Irene felt reluctant to leave her house. She started to feel cautious, nervous, suspicious and distrustful of people that she encountered within public spaces. She gradually became more insular and wary of other people walking by on the street. The possibility of verbal and/or physical violence meant that Irene felt anxious, vulnerable and exposed when walking on the street or travelling on public transport. Eventually Irene became isolated and withdrawn. Hindelang (2009) points out that for an experience of victimization to occur, the prime actors - the offender and the victim - must have the occasion to intersect in time and space. Participants in Irene's (Zempi, 2014) study argued that by removing themselves from the public space or by reducing the time spent in public places, they reduced the probability of experiencing victimization. They spoke of feeling safe by confining themselves to their home as much as possible, as this provided them with protection from being attacked in public. Many participants explained that they would only go out if it was deemed absolutely necessary. In this case the home was understood as a retreat from the hostility of the outside world and a key source of a personal sense of security (Magne, 2003).

Clearly, employing autoethnography had emotional, psychological and physiological impacts upon Irene's wellbeing. Denshire and Lee (2013: 224) state that 'putting the self into the picture at all is challenging enough in this context, but putting the very notion of a self at risk opens up places of vulnerability'. However, at the time, Irene consciously downplayed the seriousness of the situation, and felt a strong need to portray herself as 'OK' to her colleagues, family and friends because she feared that she would be prevented from completing the autoethnographic part of the research. This also meant that Irene suffered in silence and received no support with experiencing this victimization. 
Nevertheless, as will be discussed later on, the value of potentially putting herself at risk was premised on the insights into the victimization of veiled Muslim women that autoethnography provided her with, which would not have been possible had she not worn the veil herself. Gaining 'insider' knowledge is something that Irene would not have learnt from the interviews alone, especially as a non-Muslim woman researching Islamophobia.

\section{Imran's experiences 'in the field'}

Imran's experiences of harassment and intimidation as a result of his visible Muslim identity in public spaces included name-calling, swearing and threats of physical violence. Specifically, persistent staring or being ignored, being sneered and sworn at, and called a ' $\mathrm{F}^{* * * * *}$ terrorist' were part of his daily experiences in public in Birmingham. Mythen et al.'s (2009) study investigated anti-Muslim hate crime towards young British Pakistanis in the north-west of England. Their study involved a series of four focus group sessions with 32 British Muslims. They state that:

The degree of individual physical intimidation and harm endured by our respondents was sobering ... this included physical attack, being spat on, verbal abuse, damage to property and having clothing forcibly torn or removed. We would point out that we do not anticipate that our sample is unique with regards to the degree of individual victimization suffered. (Mythen et al., 2009: 743)

Correspondingly, in the following extract Imran recounts his first day in public as a 'visible' Muslim man:

My first trip was to the city centre in Birmingham, something I often do without any problems as a non-identifiable Muslim man. Before leaving, I sprinkled some Islamic attar [perfume] on my jubba, wore my Islamic cap and caught the bus to the city centre. I sat down and began reading my newspaper. After a while, a group of teenage girls sat behind me and began laughing hysterically. One of them shouted: 'Look, we have a YOU KNOW WHAT on the bus' and then one of the other girls shouted: 'Yes! We have a filthy terrorist on the bus.' I confronted them by asking them 'why did you say that?' They said 'Yes, so what if we said that? What are you gonna do about it?' I remained silent. The bus was full with people but no one came to my defence. I wanted someone to stand up for me. I wanted someone to say that I am not a terrorist just because I have a beard. I sat back on my seat and kept counting each stop. When my stop arrived, I was just so relieved I could get off the bus. When I got 
home that evening I couldn't stop thinking 'Why me? I have not done anything wrong'.

Cole and Maisuria (2007) argue that Muslims who are visibly identifiable are more likely to suffer abuse because of their appearance. They state that: 'People who appear to be of Islamic faith (wearing a veil, sporting a beard, or even carrying a backpack) are immediately identified as potential terrorists' (Cole and Maisuria, 2007: 104). The following quote is another extract from Imran's diary, which demonstrates the perpetrators' perception of Imran as a potential terrorist.

Today I drove to another suburb of Birmingham. When I got there, I parked my car and went to a shop nearby to get a cold drink as it was a very hot day in the summer. As I was walking towards the shop, I heard a loud noise from a car and two men shouting out: 'You terrorist scum'. I started walking faster and got into the shop. Fortunately, the two men did not follow me in the shop, but as I entered the shop, the customers just stopped and looked at me as if I was wearing a suicide vest. I felt a cold shiver run down my spine. I could not stay in the shop but I could not go outside either. I felt trapped.

Additionally, Imran was perceived as 'suspicious' by staff in shops and was even followed around by security guards, as the following diary extract indicates:

I was in the supermarket walking around looking to buy some food for my children. Whilst shopping, I noticed a security guard following me around, and then turning his face every time I looked back at him. At some point he came close to me and said: 'We have had some thefts happen recently. I would like to have a quick chat with you'. I felt quite upset and said: 'I'm sorry but you've got the wrong person. I have not stolen anything'. He replied: 'I'm not accusing you of stealing but I'd like to have a quick chat with you'. I said 'No, the reason you want to have a chat with me out of all the other people in this store is because I'm a Muslim'. He said: 'No sir, it's just part of our policy'. I felt humiliated, embarrassed and feeling as a second-class citizen.

Because of his Asian background, Imran also suffered verbal abuse such as ' $\mathrm{P}$ *** terrorist', which indicated both Islamophobic and racist attitudes. This indicates that link between religion and race whereby Islamophobia is understood as a 'new' form of racism (Law, 2010). From this perspective, the victimization of Muslim men can be attributed to Islamophobic attitudes as well as to racist sentiments by virtue of the fact that these elements are often inextricably 
intertwined. In this regard Islamophobia and racism become mutually reinforcing phenomena. Modood (1997) identifies that Islamophobia is at the heart of contemporary British and European cultural racism. Bhikhu (2000: 60) observes that contemporary anti-Muslim racism is 'one of the most serious forms of cultural hostility in modern Europe'. In this context, Islam is routinely portrayed as an external 'threat' to distinctly European norms and values. Similarly, Cole and Maisuria (2007) point out that Islamophobia is a product of racism and therefore racist abuse can also be viewed through the lens of Muslims being a 'risky' group. They state that, similar to other forms of racism, Islamophobia can be cultural, biological, or both. They note that: "The racist term, "Paki" co-exists with the racist term of abuse, "Bin Laden"' (Cole and Maisuria, 2007: 103). Accordingly, the following extracts from Imran's diary demonstrate the link between racism and Islamophobia:

I was walking down a busy street in Birmingham and two teenage girls walked past me and said amongst themselves: 'Get THEM out of our country!' I looked at them and said 'Our country! This is my country too'. At that point, a group of young white males stood next to the girls and told them 'Is this guy messing with you? You $\mathrm{P}^{* * *}$ scumbag'. For the first time in my entire life I was fearful for my life. I felt weak and a real sense of despair, agony, anxiety and helplessness.

Today I used the train, I noticed a group of men on the platform looking in my direction and talking angrily. I got on the train and one of them brushed me aside and shouted at me ' $\mathrm{F}^{* * * * * *}$ watch where you are going'. I apologized despite not pushing him. I sat in my seat and carried on reading my book. I was then approached by one of them who said 'Typical $\mathrm{P}^{* * *}$.' I got up and sat on another seat and the other two men followed me. I stood for the rest of my journey as I was afraid that they might actually physically attack me. When I got off the train, these men began to swear and shout abuse towards me from inside the train.

Imran portrayed himself as a 'visible' Muslim man in public spaces in Birmingham for four weeks, but he felt relieved when autoethnography was over. However, for those Muslims who are identifiable 24/7, experiencing Islamophobia is never over; rather, it is part and parcel of being visibly Muslim. Some of Imran's friends, who are visibly identifiable Muslim, had warned him: 'Imran, they will punch you and kick you and tell you "get out of our country, you don't belong here"'. In the length of time that Imran conducted this fieldwork, the impact of the abuse that he suffered was immense. As a result of these experiences, he felt embarrassed, humiliated, 'not wanted', and in some cases he started questioning whether he was 
really accepted in this country as a British Muslim. He also felt fearful, humiliated and emotionally bruised, despite not having been physically attacked. In some cases, he felt 'guilty' about his Muslim identity and its visibility. This sense of 'guilt' is demonstrated in the following extract:

I was on the bus today, and the name-calling and abuse I got made me feel humiliated. I blame myself, somehow I feel it is my fault. Even though I have not done anything wrong, I feel like someone has just punched me in my stomach. I keep asking myself 'Why? Why was I targeted and no one else on the bus? Why did they call me a "terrorist"? Why did no one step in to help me?' I look at myself in the mirror and think 'should I just shave my beard and change my clothing?' Maybe that would be easier as I would not have to suffer this abuse.

Padela and Heisler (2010), whose study assessed the discrimination faced by Arab American Muslims after 9/11, found that victims demonstrated increased levels of psychological distress. In Imran's case, writing down his feelings and experiences in the diary helped him to cope with it. However, he gradually became isolated and withdrawn; he even kept his distance from his family and friends. There were days that he would not enter into conversation with his family, and he would avoid having dinner with them or talking to them, as indicated in the extract below:

As a family we always make time to eat dinner together and discuss our day but during the fieldwork I avoided speaking to my family. At dinner, I was not hungry and my wife kept asking me 'are you ok? Has something happened today?' Instead of using this opportunity to share my feelings, emotions and experiences, I just went upstairs and tried to go to sleep. I could not forget the faces and the voices of each individual who abused me, and this made me feel even more upset. I felt angry but the overwhelming response has been one of sadness, guilt, isolation and withdrawal.

Birmingham is a diverse and multi-cultural city, and a place Imran is proud to call 'home', but his experiences of Islamophobic victimization challenged his sense of 'belonging'. In hindsight, Imran felt that he should have reported these incidents to the police but, similar to most victims of hate crime, he felt that the police would not take it seriously. Githens-Mazer and Lambert (2010) found that most Muslim Londoners who had been victims of Islamophobic hate crimes since 9/11 did not report their experiences to the police. They state that: 'While some of the more serious attacks of the kind we have illustrated have been reported to police, the 
overwhelming majority of Muslim victims of hate crimes appear not to have reported the incidents to police' (Githens-Mazer and Lambert, 2010: 38).

\section{Advantages and limitations of doing autoethnography}

Using autoethnography in order to understand victimisation and specifically Islamophobia is hugely novel in criminological ethnography. A key question that arises is whether can we research victimisation through autoethnography. Our experiences show that doing autoethnography can be a 'difficult path'. On the one hand, using autoethnography provided us with 'insider' knowledge of Islamophobic victimisation. Insider research refers to when the researcher conducts research with a group of which he or she is a member, based on characteristics such as religion, race/ethnicity, gender and sexual identity (Asselin, 2003; Kanuha, 2000). Insider research is considered to be from an emic perspective, as it involves the description of a phenomenon that is understood by the researcher who has also experienced it (Spiers, 2000). Being of an insider position is associated with various advantages, such as promoting a more balanced understanding of the research population and the transference of information from the participant to the researcher (Labaree, 2002). This can be particularly useful in research with groups that have been under-represented, oppressed or marginalised. At the same time, outsider researchers are accused of lacking understanding (Savvides et al., 2014). From this perspective, it is argued that outsiders cannot understand or represent accurately the experiences of their participants. This is a particularly salient topic when research is conducted with stigmatised, 'other' communities (Hayfield and Huxley, 2015).

As mentioned earlier, Imran has been investigating Islamophobia for the last decade. Although he is Muslim, Imran has never experienced Islamophobic abuse in public, possibly because his Muslim identity is not 'visible'. Therefore, although he could be perceived as an 'insider' based on his religion, he could also be seen as an 'outsider' on the basis of his non-visible Muslim identity. Indeed, Imran was criticised by one of his participants as lacking understanding because of his nonvisible Muslim identity. For Irene, being an Orthodox Christian female researcher meant that she was perceived as an 'outsider' by her participants. Using autoethnography enabled us to see the world through the eyes of our participants; nevertheless, we were not fully insiders. Rather, autoethnography provided us with an 'outsider within' status which generated a distinctive standpoint vis-à-vis existing sociological paradigms (Hill Collins, 1986). Mohanty (2001) highlights the unique standpoint that the 'outsider within status' can generate. To this end, we developed a particular way of seeing reality. In the words of Hooks (1984: vii), 'we looked from the outside and in from the inside outside ... we understood both'. Hill Collins (1986) notes that despite the obstacles of being an outside within, researchers can benefit from this status. Hill Collins (1986) notes the ability of the 'outsider within' researcher to see patterns that maybe more difficult for those 
immersed in the situation to see. As 'outsiders within', we have enriched contemporary sociological discourse on Islamophobic victimisation (Mohanty, 2001). Correspondingly, our 'outsider within' status helped us to accurately interpret participants' stories, and represent their 'voices' regarding the nature, extent, and impact of Islamophobic victimisation. Becoming 'visible' Muslim helped us to deepen our empathy and understanding of the targeted victimisation of 'visible' Muslim men and women in public spaces in the UK.

Our goal was to see the world through someone else's eyes, using ourselves and specifically our bodies, as a research instrument. That said, we do not argue that one needs to turn oneself into a victim and to experience victimhood, in order to write about it. We acknowledge that this would be both analytically and ethically problematic. Rather, our approach was a process of exploration, exploring an empirically still unknown territory: employing autoethnography to research Islamophobia. This approach highlights the 'emotional labour' that is required to make the connections between experiences and insight/knowledge. The term of 'emotional labour' was initially developed by Hochschild (1983), who explored the experiences of flight attendants and how they managed their emotions on a day-to-day basis on the job. Hochschild (2003: 7) argued that qualitative research often involves a form of 'emotional labour', a situation where one is required 'to induce or suppress feeling in order to sustain the outward countenance that produces the proper state of mind in others' (2003: 7). Hochschild (1983) referred to the 'human costs' of emotional labour, from 'burnout' to feeling 'phony', 'guilt' and 'self blame'.

It is clear from the data presented here that we both undertook a significant amount of emotion work. From the perspective of 'emotional labour', there were certain 'costs' involved in both studies. Feelings of emotional exhaustion and physical distress emerged because of the intimidation, abuse and hostility we experienced from members of the public. Thus doing autoethnography allowed us to experience many of the emotions that victims feel when they experience Islamophobia such as depression, sadness, fear, anxiety, suspicion, anger, helplessness and isolation. Dickson-Swift et al. (2009) note that qualitative researchers working with particularly traumatic material may be subject to a degree of vicarious traumatisation. Vicarious traumatisation can be defined as the process by which individuals listening to and working with the traumatic experiences of others begin to experience the effects of trauma themselves. Using Goffman's (1959) work on social identities, we felt that our 'virtual social identities' (the way we were perceived by others) entirely eclipsed our 'actual social identities'. This led us both to a loss of a sense of 'self', which prompted questions such as: who am I; what am I doing/have I done this for; what do I think about what is going on here; am I allowed to have opinions on the things I am observing; what is/was the point of this; and where do I fit in now? 
Moreover, doing autoethnography entailed certain ethical problems in both cases. As Campbell (2016: 100) notes, "the central maxim for the ethical researcher is 'do no harm". From this perspective, all researchers - regardless of whether they are using qualitative, quantitative or mixed methods - must take into consideration the effect their study will have on any human participants. In traditional research, one of the ways of countering any ethical issues is to obtain informed consent from the study participants. In autoethnographical studies, one might argue that informed consent in implicit, as the only participant is the researcher; however, for Sikes (2008) autoethnographical accounts put the researcher on 'dodgy ground'. As Campbell (2016) points out, it is inevitable that other people will be (in)direct participants in autoethnographic research. It is not always possible to obtain consent from people when we do not know if and how they will be part of the story. She argues that it is not practically feasible to say to people that 'I am an autoethnographer and I might write something which may or may not have a connection to you one day' (Campbell, 2016: 103). In both our studies, although it was not possible to get their consent, we ensured complete anonymity for members of the public. Moreover, we did not engage in activities such as audio or video recording, which could have potentially revealed people's identity.

At the same time though, using autoethnography in the form of covert research entails additional ethical problems. During the process of autoethnography, we assumed a covert role and did not disclose to members of the public that we were researchers. Admittedly, using autoethnography in the form of covert research is perhaps ethically dubious due to there being a level of deception involved. We both developed feelings of emotional distress as a result of this. As Lofland and Lofland (1995) point out, researchers may feel uncomfortable if they deceive the people being observed when they do not totally reveal the true nature of their study. However, covert research can uncover phenomena that would otherwise remain inscrutable. We argue that assuming a covert role was essential to the success of our research projects. It is highly likely that people's awareness of our status as researchers would influence how they treated us, which would potentially mask the true dimensions of public expressions of Islamophobic prejudice and hostility. Therefore, although there are important ethical questions here, the fact remains that in this instance, withholding our true identity was entirely ethically defensible.

Finally, it is perhaps no coincidence that the nature, extent and impact of Islamophobic hostility that we experienced when doing autoethnography echoes visible Muslims' experiences of Islamophobic victimisation. This shows that the themes we have identified as important when conducting autoethnography on Islamophobic victimisation resonate with themes that echo aspects of visible 
Muslims' experiences of Islamophobic victimisation. That said, we are both of the view that it is not possible for 'outsiders', no matter how skilled in (auto)ethnographic technique, to ever fully grasp the experience of being visibly Muslim on the basis that they live in a context where they are vulnerable 24/7. Their experiences of Islamophobic victimisation will always be more authentic and the emotional, psychological and physical impacts will be exponentially more deeply felt. However, it is important to recognise that autoethnography provided us with a unique insight into visible Muslims' vulnerability to Islamophobic victimisation in public. Through our projects, we were able to identify the role of the 'visibility' of our (perceived) Muslim identity in 'triggering' Islamophobic hostility in public spaces. For Irene, it is her non-Muslim background that makes her experiences so useful in terms of recognising the role of wearing the veil as a 'trigger' to Islamophobic attacks. Similarly, Imran would not have been abused had he not wore the jubba and grew a beard. The fact that we do not normally wear Islamic clothes allowed us to see the difference in people's behaviour in public spaces, and expose the problem.

\section{Conclusion}

In this paper, we have reflected upon our personal experiences of undertaking autoethnography on Islamophobic victimisation. Despite our 'outsider' status (as an Orthodox Christian researcher for Irene and a non-visible Muslim researcher for Imran), we used autoethnography purposefully and tactically in order to research the experiences of victimised 'others'. This approach is extremely novel in criminological ethnography. Purposeful attempts to research victimisation through autoethnography are literally unheard of. In light of the high emotional and physical demand of autoethnography, a key question that arises is whether can we research Islamophobic victimisation through autoethnography. Our experiences of doing autoethnography show that this research method can be a 'difficult path'. On the one hand, using autoethnography allowed us to gain 'insider' knowledge. In this regard, gaining 'insider' knowledge contributed to the process of understanding visible Muslims' experiences of Islamophobic victimisation in public. On the other hand, there were certain 'costs' involved. Using our own experiences as the vehicle, we illustrated the harmful effects of Islamophobic abuse such as emotional, psychological and physical impacts. Indeed, fieldwork evoked feelings of guilt, sadness and anger, leaving us upset and depressed. Moreover, there were ethical as well as moral issues involved such as putting ourselves at risk and doing covert research. We agree with Taber (2010: 5) who states that 'researchers must continually push methodological boundaries in order to address research questions that cannot be explored with traditional methods'. However, it is important that the risks presented by autoethnographic research on victimisation are balanced against the opportunities to generate appreciative criminological data. 


\section{References}

Abbas T (2004) After 9/11: British South Asian Muslims, Islamophobia, multiculturalism, and the state. American Journal of Islamic Social Sciences 21(3): 26-38.

Allen C (2010) Islamophobia. Surrey: Ashgate.

Allen C, Isakjee A and Young O (2013) Understanding the Impact of Anti-Muslim Hate on Muslim Women. Birmingham: University of Birmingham.

Anderson L (2006) Analytical autoethnography. Journal of Contemporary Ethnography 35(4): 373-395.

Asselin ME (2003) Insider research: Issues to consider when doing qualitative research in your own setting. Journal for Nurses in Staff Development 19: 99-103.

Bouteldja N (2011) Unveiling the Truth: Why 32 Muslim Women Wear the Full face Veil in France. London: Open Society Foundations.

Boutelja N (2014) France vs. England. In: Brems E (ed) The Experiences of Face Veil Wearers in Europe and the Law. Cambridge: Cambridge University Press, pp.115-160.

Bowling B (2009) Violent Racism: Victimisation, Policing and Social Context. In: Williams B and Goodman-Chong H (eds) Victims and Victimisation: A Reader. Maidenhead: Open University Press, pp.45-57.

Brems E (2014) Introduction to the volume. In: Brems E (ed) The Experiences of Face Veil Wearers in Europe and the Law. Cambridge: Cambridge University Press, pp.1-17.

Campbell E (2016) Exploring Autoethnography as a Method and Methodology in Legal Education Research. Asian Journal of Legal Education 3(1): 95-105.

Chang H (2016) Autoethnography in Health Research: Growing Pains? Qualitative Health Research 26(4): 443-451.

Charmaz K (2006) Constructing Grounded Theory: a Practice Guide through Qualitative Analysis. London: Sage.

Cole M and Maisuria A (2007) 'Shut the $\mathrm{f}^{* * *}$ up', 'you have no rights here': Critical Race Theory and Racialisation in post-7/7 racist Britain. Journal for Critical Education Policy Studies 5(1): 1-27. 
Crewe B (2009) The Prisoner Society: Power, Adaptation, and Social Life in an English Prison. Oxford: Oxford University Press.

Curtis B and Curtis C (2011) Social Research. London: Sage.

Denshire S and Lee A (2013) Conceptualizing autoethnography as assemblage: Accounts of occupational therapy practice. International Journal of Qualitative Methods 12: 221-236.

Denzin NK (2006) Analytic autoethnography, or de ja vu all over again. Journal of Contemporary Ethnography 35(4): 419-428.

Ellis C and Bochner AP (2000) Autoethnography, personal narrative, reflexivity. In: Denzin NK and Lincoln YS (eds) Handbook of qualitative research. Thousand Oaks, CA: Sage, pp. 733-768.

Ellis C and Bochner A (2006) Analysing analytical autoethnography: An autopsy. Journal of Contemporary Ethnography 35(4): 429-449.

Esposito JL and Kalin I (2011) Islamophobia: The Challenge of Pluralism in the 21st Century. Oxford: Oxford University Press.

Ferrell J (2006) Empire of the Scrounge: Inside the Urban Playground of Dumpster Diving, Trash Picking and Street Scavenging. New York: New York University Press.

Githens-Mazer J and Lambert R (2010) Islamophobia and Anti-Muslim Hate Crime: A London Case Study. London: European Muslim Research Centre.

Goffman E (1959) The Presentation of Self in Everyday Life. New York: Doubleday.

Grillo R and Shah P (2012) Reasons to Ban? The Anti-Burqa Movement in Western Europe. Göttingen: Max Planck Institute.

Hayano DM (1979) Auto-ethnography: Paradigms, problems, and prospects. Human Organization 38: 113-120.

Hayfield N and Huxley C (2015) Insider and outsider perspectives: Reflections on researcher identities in research with lesbian and bisexual women.' Qualitative Research in Psychology 12(2): 91-106. 
Heider H (1975) What Do People Do? Dani Auto-Ethnography. Journal of Anthropological Research 31(1): 3-17.

Hennink M, Hutter I and Bailey A (2011) Qualitative Research Methods. London: Sage.

Hindelang M (2009) Towards a Theory of Personal Criminal Victimisation. In: In: Williams B and Goodman-Chong H (eds) Victims and Victimisation: A Reader. Maidenhead: Open University Press, pp.26-40.

Hopkins PE (2007) Global events, national politics, local lives: young Muslim men in Scotland. Environment and Planning 39(5): 1119-1133.

Hochschild A (1983) The managed heart: Commercialization of human feeling. Berkeley: University of California Press.

Hooks B (1984) Feminist Theory: From Margin to Center. Boston: South End Press.

Jewkes Y (2011) Autoethnography and Emotion as Intellectual Resources: Doing Prison Research Differently. Qualitative Inquiry 18: 63-75.

Kanuha VK (2000) Being Native versus "going Native": Conducting social work research as an insider Social Work 45(5): 439-447.

Labaree RV (2002) The risk of 'going observationalist': negotiating the hidden dilemmas of being an insider participant observer. Qualitative Research 2(1): 97 122 .

Law I (2010) Racism and Ethnicity: Global Debates, Dilemmas, Directions. London: Pearson Education.

Liebling A (1999) Doing Research in Prison: Breaking the Silence? Theoretical Criminology 3: 147-173.

Lofland J and Lofland L (1995) Analysing Social Settings. California: Wadsworth Publications Company.

Mac an Ghaill M and Haywood C (2014) Pakistani and Bangladeshi young men: reracialization, class and masculinity within the neo-liberal school. British Journal of Sociology of Education 35(5): 753-776. 
Magne S (2003) Multi-Ethnic Devon: A Rural Handbook - The Report of the Devon and Exeter Racial Equality Council's Rural Outreach Project, Devon: Devon and Exeter Racial Equality Council.

Modood T (1997) Difference, Cultural Racism and Anti-Racism. In Modood T and Werbner P (eds) Debating Cultural Hybridity. London: Zed Books.

Mohanty CT (2003) 'Under Western Eyes' Revisited: Feminist Solidarity through Anticapitalist Struggles. Signs: Journal of Women in Culture and Society 28 (2): 499-535.

Moors A (2009) The Dutch and the Face-Veil: The Politics of Discomfort. Social Anthropology 17(4): 393-408.

Moors A (2014) Face veiling in the Netherlands: public debates and women's narratives. In: Brems E (ed) The Experiences of Face Veil Wearers in Europe and the Law. Cambridge: Cambridge University Press, pp.19-41.

Moosavi L (2014) The Racialization of Muslim Converts in Britain and Their Experiences of Islamophobia. Critical Sociology 41(1): 41-56.

Payne S (2004) Designing and conducting qualitative studies. In Health psychology in practice, edited by Michie, S. and Abraham, C., 126-149. London: Routledge.

Perry B and Alvi S (2012) We Are All Vulnerable: The in Terrorem Effects of Hate Crimes. International Review of Victimology 18(1): 57-71.

Phillips C and Earle R (2010) Reading Difference Differently? Identity, Epistemology and Prison Ethnography. British Journal of Criminology 50: 360378.

Poynting S and Mason V (2007) The resistible rise of Islamophobia: Anti-Muslim racism in the UK and Australia before 11 September 2001. Journal of Sociology 43(1): 61-86.

Sayyid S and Vakil A (2011) Thinking through Islamophobia: Global Perspectives. London: Hurst and Co.

Scott WJ (2007) The Politics of the Veil. Princeton: The Princeton University Press. 
Styhre A and Tienari J (2014) Men in context: privilege and reflexivity in academia. Equality, Diversity and Inclusion: An International Journal 33(5): 442-450.

Sikes P (2006) On Dodgy Ground? Problematics and Ethics in Educational Research? International Journal of Research \& Method in Education 29(1): 105117.

Spiers J (2000) New perspectives on vulnerability using emic and etic approaches. Journal of Advanced Nursing 31(3): 715-721.

Taber N (2010) Institutional ethnography, autoethnography, and narrative: an argument for incorporating multiple methodologies. Qualitative Research 10 (5): 5-25.

Savvides N, Al-Youssef J Colin M and Garrido C (2014) Journeys into Inner/Outer Space: Reflections on the Methodological Challenges of Negotiating Insider/Outsider Status in International Educational Research. Research in Comparative and International Education 9(4): 412-425.

Sparkes AC (2000) Autoethnography and narratives of self: Reflections on criteria in action. Sociology of Sport Journal 17: 21-43.

Spiers J (2000) New perspectives on vulnerability using emic and etic approaches. Journal of Advanced Nursing 31(3): 715-721.

Taber N (2010) Institutional ethnography, autoethnography, and narrative: an argument for incorporating multiple methodologies. Qualitative Research 10(5): 5-25.

Yuval-Davis N (2011) The Politics of Belonging: Intersectional Contestations. London: Sage.

Wakeman S (2014) Fieldwork, Biography and Emotion: Doing Criminological Autoethnography. British Journal of Criminology 54(5): 705-721.

Wall S (2006) An autoethnography on learning about autoethnography. International Journal of Qualitative Methods 5(2): 1-12.

Walters M, Brown R and Wiedlitzka S (2016) Preventing hate crime: emerging practices and recommendations for the effective management of criminal justice interventions. Sussex: Sussex Crime Research Centre. 